\title{
Analisis Intensitas Curah Hujan Di Gampong Kapa Kecamatan Langsa Timur
}

\author{
Vina Asmara ${ }^{1}$, Nirmala Sari ${ }^{2}$ \\ 1,2 Jurusan Fisika, Teknik, Universitas Samudra \\ *Co-Author: Asmaravina88@gmail.com
}

\begin{abstract}
.
Telah dilaksanakan Pengamatan dengan judul Analisis Intensitas Curah Hujan di Gampong Kapa Kecamatan Langsa Timur dengan tujuan mengetahui Prinsip kerja dari alat ombrometer dan mengetahui tipe iklim dari intensitsas curah hujan tertinggi selama lima tahun terakhir di Gampong Kapa Kecamatan Langsa Timur. Metode yang digunakan dalam kerja praktek ini yaitu metode studi lapangan yang meliputi pengamatan, peninjauan dan mempelajari secara langsung bagaimana prinsip kerja dari alat ombrometer atau penangkar hujan dan menganalisis intensitas curah hujan dari data tahun 2016 hingga tahun 2020. Alat penangkar hujan ini bekerja dengan cara air hujan akan masuk kedalam penangkar melalui corong yang ada diatas penangkar dan akan tersimpan didalam tabung penangkar lalu dilakukan pengukuran dengan menggunakan gelas standart BMKG. Dari kerja praktek yang telah dilaksanakan didapatkan hasil bahwasanya pada tahun 2019 tergolong kedalam curah hujan dengan intensitas tertinggi dengan total curah hujan 1564,5 mm dengan rata-rata 130,4 dan terdapat sebanyak 2 bulan kering (bulan febuari dan bulan maret), dan terdapat sebanyak 8 bulan basah (bulan januari, april, juni, agustus, september, oktober, november, dan desember), dan terdapat sebanyak 2 bulan lembab (bulan mei dan bulan juli). Kemudian dianalisis intensitasnya menunjukan nilai 25\%. Berdasarkan hasil analisis intensitas curah hujan pada tahun 2019 di Gampong Kapa Kecamatan Langsa Timur termasuk kedalam tipe iklim B, yaitu daerah basah, hutan hujan tropika.
\end{abstract}

Kata Kunci: Ombrometer, Curah Hujan, Tipe Iklim

\section{PENDAhUluan}

Balai Penyuluhan Pertanian Kecamatan Langsa Timur berada dibawah naungan Dinas Pangan, Pertanian, Kelautan dan Perikanan Kota Langsa, yang merupakan salah satu dari tiga Balai Penyuluhan Pertanian yang ada di Kota Langsa. Lokasi Balai Penyuluhan Pertanian ini di Jalan Medan-Banda Aceh Km. 4,5 Gampong Kapa Kecamatan Langsa Timur Kota Langsa, Provinsi Aceh. Di Balai Penyuluhan Pertanian Langsa Timur terdapat alat pengukur curah hujan yang dinamakan Ombrometer. Alat Ombrometer ini berfungsi untuk mengukur curah hujan yang jatuh ke permukaan tanah. Curah hujan adalah jumlah air hujan yang jatuh selama waktu tertentu. Unsur-unsur hujan yang harus diperhatikan dalam mempelajari curah hujan adalah jumlah curah hujan, dan intensitas atau kekuatan tetesan hujan [1].

Intensitas curah hujan adalah banyaknya curah hujan persatuan jangka waktu tertentu [2]. Alat Ombrometer atau pengukur curah hujan dipasang ditempat terbuka, sehingga air hujan dapat ditampung langsung oleh alat ini. Satuan yang digunakan adalah milimeter (mm) dengan ketelitian pembacaannya sampai dengan 0,1 $\mathrm{mm}$ [3]. Dari banyaknya curah hujah menurut pendapat Schmidt-Fergusson dapat di klasifikasikan menjadi beberapa tipe iklim antara lain sangat basah, basah, agak basah, sedang, agak kering, kering, sangat kering, dan luar biasa kering [4]. Perubahan iklim dan cuaca disebabkan oleh efek global warming. Salah satu dampak yang ditimbulkan adalah meningkatnya intensitas curah hujan, apabila dikatakan intensitas curah hujannya besar berarti dikategorikan hujan lebat dan kondisi ini sangat berbahaya karena dapat menimbulkan banjir, longsor dan efek negatif terhadap tanaman [2]. Oleh karena itu diperlukan Analisis Intensitas Curah Hujan Di Gampong Kapa Kecamatan Langsa Timur.

\section{METODE PENELITIAN}

Metode yang digunakan dalam pengamatan ini yaitu metode studi lapangan yang meliputi pengamatan, peninjauan dan mempelajari secara langsung bagaimana prinsip kerja dari alat ombrometer dan menganalisis intensitas curah hujan dari data tahun 2016 hingga tahun 2020. Prinsip kerja ombrometer sebagai berikut:

1. Saat terjadinya hujan, maka air akan masuk kedalam corong penangkar.

2. Air yang masuk kedalam penangkar akan mengalir dan terkumpul didalam tabung penangkar.

3. Letakan gelas ukur dibawah kran alat penangkar untuk menampung airnya untuk diukur.

4. Apabila jumlah curah hujan melebihi kapasitas gelas ukur, maka dilakukan pengukuran berulang.

5. Kemudian lakukan pembacaan dan catat hasil pengukurannya [5]

Pengamatan curah hujan ini dilakukan di BPP Langsa Timur Gampong Kapa kecamatan Langsa Timur. Pada saat hujan, air akan masuk kedalam penangkar curah hujan melalui corong yang ada diatas penangkar. pengukuran dilakukan pada 
pagi hari, air yang sudah tertampung di ukur dengan gelas ukur $25 \mathrm{~mm}$ standar BMKG, lalu dilihat ukurannya, jika melebihi $25 \mathrm{~mm}$ maka dilakukan pengukuran berulang sampai air di alat penangkar habis dan catat hasil curah hujannya, jika curah hujan mencapai $100 \mathrm{~mm}$ per hari maka hasil pengukuran langsung di laporkan ke BMKG untuk memperkirakan cuaca. Jika hasil dari pengukuran curah hujan tidak sampai $100 \mathrm{~mm}$ perhari maka selama 10 hari sekali dilaporkan ke BMKG, dan BMKG akan mengirim perkiraan cuaca 10 hari kedepannya.

\section{HASIL DAN PEMBAHASAN}

Tabel 1 merupakan data curah hujan dari tahun 2016 sampai 2020 di Balai Penyuluhan Pertanian Gampong Kapa Kecamatan Langsa Timur Kota Langsa, menunjukan intensitas curah hujan yang berbeda-beda disetiap tahunnya. Untuk lebih jelasnya dapat dilihat pada tabel dibawah ini.

Tabel 1. Data Intensitas Curah Dari Tahun 2016-2020 Di Gampong Kapa Kecamatan Langsa Timur

Grafik

\begin{tabular}{|c|c|c|c|c|c|c|c|c|c|c|c|}
\hline \multirow[t]{3}{*}{$\mathrm{NO}$} & \multirow[t]{3}{*}{ Bulan } & \multicolumn{10}{|c|}{ Tahun } \\
\hline & & \multicolumn{2}{|c|}{2016} & \multicolumn{2}{|c|}{2017} & \multicolumn{2}{|c|}{2018} & \multicolumn{2}{|c|}{2019} & \multicolumn{2}{|c|}{2020} \\
\hline & & $\mathrm{Hh}$ & $\mathrm{Mm}$ & $\mathrm{Hh}$ & $\mathrm{Mm}$ & $\mathrm{Hh}$ & $\mathrm{Mm}$ & $\mathrm{Hh}$ & $\mathrm{Mm}$ & $\mathrm{Hh}$ & $\mathrm{Mm}$ \\
\hline 1 & Januari & 2 & 35 & 17 & 269 & 12 & 53 & 7 & 145 & 4 & 6 \\
\hline 2 & Febuari & 5 & 165 & 6 & 44 & 7 & 100,5 & 3 & 34 & 7 & 61 \\
\hline 3 & Maret & - & - & 6 & 45 & 5 & 20,5 & 1 & 5 & 0 & 0 \\
\hline 4 & April & 1 & 3 & 4 & 13 & 11 & 89 & 6 & 153,5 & 10 & 160,5 \\
\hline 5 & Mei & 4 & 55 & 13 & 127,5 & 13 & 99,2 & 12 & 75,5 & 14 & 121,5 \\
\hline 6 & Juni & 15 & 136 & 7 & 33 & 9 & 89,5 & 13 & 147,5 & 10 & 174 \\
\hline 7 & Juli & 7 & 120 & 9 & 61 & 11 & 56,5 & 7 & 83 & 13 & 122,5 \\
\hline 8 & Agustus & 12 & 139 & 18 & 275 & 16 & 171,5 & 10 & 125 & 9 & 83 \\
\hline 9 & September & 9 & 110 & 16 & 182,5 & 17 & 313 & 14 & 193,5 & 16 & 190,5 \\
\hline 10 & Oktober & 7 & 101 & 15 & 146 & 20 & 233,5 & 15 & 151,5 & 19 & 167 \\
\hline 11 & November & 13 & 179 & 13 & 77,5 & 16 & 233,8 & 13 & 230,5 & 19 & 190 \\
\hline 12 & Desember & 14 & 321 & 19 & 237,5 & 8 & 59 & 16 & 230,5 & 18 & 246 \\
\hline & Total & 89 & 1.364 & 143 & 1.511 & 145 & 1.519 & 117 & $1.564,5$ & 139 & 1.522 \\
\hline & ata-rata & 7 & 113,7 & 12 & 125,9 & 12 & 127 & 9,7 & 130,4 & 11,6 & 126,8 \\
\hline
\end{tabular}

intensitas curah hujan tahun 2016 sampa tahun 2020 di Gampong Kapa Kecamatan Langsa Timur

\section{Intensitas Rata-Rata Curah Hujan}

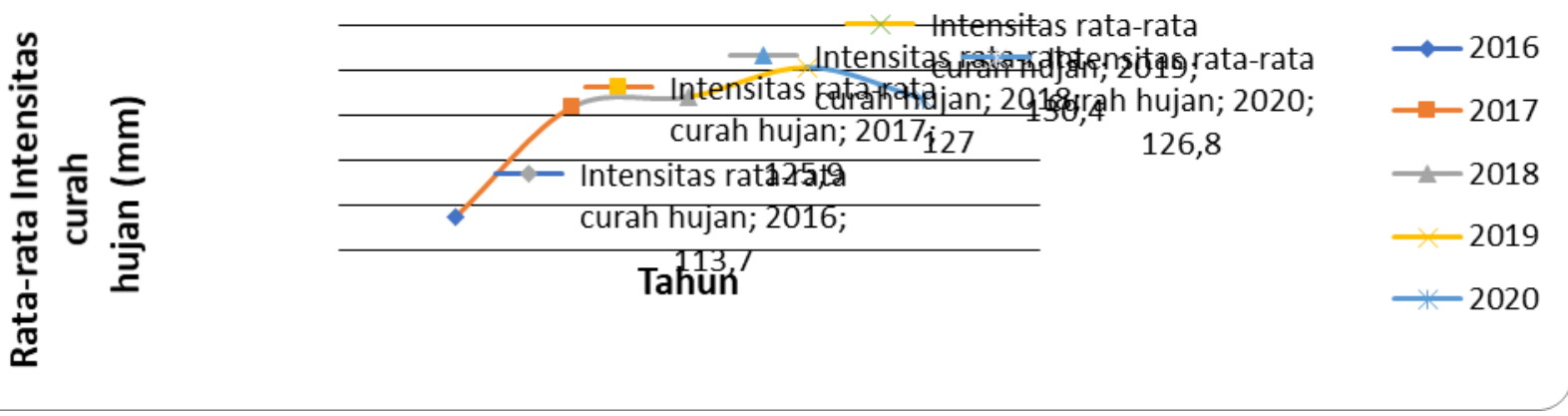

Gambar 1. Grafik Rata-Rata Intensitas Curah Hujan Dari Tahun 2016-2020 Di Gampong Kapa Kecamatan Langsa Timur.

Dari grafik diatas menunjukkan bahwa intensitas curah hujan di Gampong Kapa Kecamatan Langsa Timur mengalami kenaikan dari tahun 2016 hingga tahun 2019 dan mengalami penurununan pada tahun 2020. Dari Tabel 1 terlihat bahwa intensitas hujan yang tinggi pada tahun 2019 berlangsung dalam durasi pendek. Hal tersebut berarti bahwa hujan deras pada umumnya berlangsung dalam waktu singkat namun hujan tidak deras bisa berlangsung dalam waktu lama [6].

Untuk kriteria bulan kering <60 mm, bulan basah >100 dan bulan lembab 60-100 mm, menurut klasifikasi iklim Schmidt-Fergunson yang menggunakan nilai perbandingan $(\mathrm{Q})$ antara rata-rata banyaknya bulan kering dan rata-rata banyaknya bulan basah (\%) maka dikelompokkan menjadi 8 tipe iklim [4]. Dari persamaan Schmidt-Fergusson, analisis intensitas curah hujan Tahun 2016 yaitu:

Dik: bulan kering $(<60 \mathrm{~mm})=4$ (bulan Januari, Maret, April, dan Mei)

bulan basah $(>100 \mathrm{~mm})=8$ (bulan Febuari, Juni, Juli, Agustus, September,

Oktober, November, Desember) 


$$
\begin{aligned}
& Q=\frac{j u m l a h \text { bulan kering }}{j \text { umlah bulan basah }} \times 100 \% \\
& Q=\frac{4}{8} \times 100 \%=50 \%
\end{aligned}
$$

Hasil analisis intensitas curah hujan dari tahun 2016 sampai 2020 adalah:

1. Pada tahun 2016 menunjukan nilai 50\%. Menurut Schmidt-Fergusson berdasarkan hasil analisis intensitas curah hujan, di Gampong Kapa Kecamatan Langsa Timur termasuk kedalam tipe iklim C, yaitu daerah agak basah, hutan rimba, daun gugur pada musim kemarau.

2. Pada tahun 2017 menunjukan nilai 66,6\%. Menurut Schmidt-Fergusson berdasarkan hasil analisis intensitas curah hujan, di Gampong Kapa Kecamatan Langsa Timur termasuk kedalam tipe iklim D, yaitu daerah sedang, hutan musim.

3. Pada tahun 2018 menunjukan nilai 80\%. Menurut Schmidt-Fergusson berdasarkan hasil analisis intensitas curah hujan, di Gampong Kapa Kecamatan Langsa Timur termasuk kedalam tipe iklim D, yaitu daerah sedang, hutan musim.

4. Pada tahun 2019 menunjukan nilai 25\%. Menurut Schmidt-Fergusson berdasarkan hasil analisis intensitas curah hujan, di Gampong Kapa Kecamatan Langsa Timur termasuk kedalam tipe iklim B, yaitu daerah basa, hutan hujan tropika.

5. Pada tahun 2020 menunjukan nilai $25 \%$. Menurut Schmidt-Fergusson berdasarkan hasil analisis intensitas curah hujan, di Gampong Kapa Kecamatan Langsa Timur termasuk kedalam tipe iklim B, yaitu daerah basa, hutan hujan tropika.

\section{KESIMPULAN}

a. Kesimpulan

Kesimpulan yang diperoleh dari pengamatan ini adalah:

1. Ombrometer adalah alat untuk menampung air hujan yang masuk ke dalam tabung penangkar hujan yang akan diukur menggunakan gelas ukur $25 \mathrm{~mm}$ standar BMKG.

2. Dari data curah hujan di Gampong Kapa Kecamatan Langsa Timur selama lima tahun terakhir dari tahun 2016 2020 menunjukkan intensitas curah hujan tertinggi pada tahun 2019 dan termasuk kedalam tipe iklim B, yaitu daerah basa, hutan hujan tropika.

\section{DAFTAR PUSTAKA}

[1] D. A . Perdana. \& A. Zakaria," Studi Pemodelan Curah hujan sintetik dari beberapa stasiun di wilayah Pringsewu," JRSDD 3(1), 45-56,2015.

[2] N. Ihsan, \& J. Fisika, " Analisis pola dan intensitas curah hujan berdasakan data observasi dan satelit tropical rainfall measuring missions (trmm) $3 b 42$ v7 di makassar," urnal Sains Dan Pendidikan Fisika (JSPF) Jilid 11 Nomor 1, 98-103, 2015.

[3] I. C . Choiriyah, " Prototipe Perancangan Alat Pengukur Curah Hujan Otomatis Tipe Hellman Berasis Ardoino Uno," Digital Respository Universitas Jember, 2018.

[4] R. A. Sasminto, A. Tunggul, \& J. B. Rahadi, " Analisis Spasial Penentuan Iklim Menurut Klasifikasi SchmidtFerguson dan Oldeman di Kabupaten Ponorogo," Jurnal Sumberdaya Alam Dan Lingkungan, 1(1), 51-56, 2014.

[5] Agusta Kurniawan." Evaluasi Pengukuran Curah Hujan Antara Hasil Pengukuran Permukaan ( AWS , HELLMAN, $O B S$ ) dan Hasil Estimasi ( Citra Satelit)," Jurnal Geografi, Edukasi dan Lingkungan (JGEL) Vol. 4, No. 1, Januari 2020:1-7

[6] Susilowati." Kajian Pemamfaatan Pemanenan Air Hujan Skala Individu Untuk Kebutuhan Air Bersih Pada Pulau Keci," Jurnal Konstruksia, 7(1), 2015. 